\title{
Facilitating factors of scientific literacy skills development among junior high school students
}

\author{
Kareen Marie E. Palines ${ }^{1}$ and Ruth A. Ortega-Dela Cruz ${ }^{2}$ \\ ${ }^{1}$ Department of Education, Division of Calauan, Laguna, Philippines \\ ${ }^{2}$ University of the Philippines Los Baños, Laguna, Philippines
}

The study used causal-comparative research design to examine the scientific literacy among randomly selected Junior High School students under the Science, Technology and Engineering Program (STEP) of a National High School in the Philippines. Specifically, it investigated the factors that facilitate and hinder the students' ability to write and present scientific research. Quantitative and qualitative data were gathered from primary and secondary sources. Descriptive statistics were used to analyse the data obtained from the interviews and questionnaires. Findings showed that the scientific literacy of students in terms of writing was perceived as good while presenting the scientific research was described as fair. The study also revealed that teachers' factors, learning environment, and school administrative support affect the scientific literacy skills development of the students. Thus, the study suggested that by promoting the identified factors, the scientific literacy skills of the students will be further developed. Additionally, increase of teacher's availability during consultation hours, use of differentiated instructions, localization, contextualization, formulation of policy guidelines for the use of learning resources, plan of activities for STEP, as well as development of a module, research networks and linkages should be given importance.

\author{
ARTICLE DETAILS \\ LUMAT General Issue \\ Vol 9 No 1 (2021), 546-569 \\ Received 20 February 2021 \\ Accepted 11 June 2021 \\ Published 11 August 2021 \\ Pages: 24 \\ References: 41 \\ Correspondence: \\ raortegadelacruz@up.edu.ph \\ https://doi.org/10.31129/ \\ LUMAT.9.1.1520
}

Keywords: facilitating factors, high school students, scientific literacy, skills development

\section{Introduction}

Scientific literacy, which consists of the knowledge and understanding of the scientific concepts and processes required for personal decision making, participation in civic and cultural affairs and economic productivity (Mohapatra, 2013) is an important factor of development in every nation. It is an important factor of social and economic progress (Rodriguez-Espinosa, 2005). According to Dragoş and Mih (2015), scientific literacy can be classified into four categories. These include (i) Cultural Scientific Literacy, which is the understanding of science with average intelligence and education of a culture; (ii) Civic Scientific Literacy, which is the understanding of science in order to make informed decisions with regard to legislation and public policy; (iii) Scientific Literacy Practice, which is the understanding of science in order to solve practical problems; and (iv) Aesthetic Literacy and Consumer Science, which is the understanding of scientific laws and phenomena that enhances a person's 
appreciation of life itself through intellectual beauty of scientific ideas.

In general, science as a subject taught in every school should support the development of scientific literacy. This will prepare students for a more complex, interconnected world, with jobs that require critical thinking, teamwork and problemsolving skills. In fact, scientific literacy is one of the essential skills required in this digital age literacy (Turiman, Omar, Daud, \& Osman, 2012). Thus, science education shall help the students and motivate them in pursuing careers in line with science and its application to technology and the industry.

In the process of teaching and learning science, news reports in 2017 from the Philippine Inquirer show that Filipino students exhibit high regard in science by applying the concepts through an invention or innovation and joining several science competitions in the national and international arena (Leonen, 2017).

On the contrary, it has also been reported that the state performance of Filipino students in science national and international examinations remained poor. The Philippine Department of Education (DepEd) recognizes the need for addressing this issue on scientific literacy after the country got a poor ranking in the Programme for International Student Assessment (PISA) in 2018. The PISA is a student assessment of 15-year-old learners across 79 countries done by the Organization for Economic Cooperation and Development (OECD) as part of the Quality Basic Education reform plan and a step towards globalizing the quality of Philippine basic education (DepEd, 2019). It looks into the extent to which the students have acquired key knowledge and skills that are essential for full participation in modern societies (OECD, 2018). Based on the PISA results, the Filipino students scored 357 in Scientific Literacy, which was significantly lower than the Organisation for Economic Co-operation and Development (OECD) average of 489 points.

Science Literacy, as defined in the PISA 2018 Assessment and Analytical Framework, refers to the students' ability to engage with science-related issues, and with the ideas of science, as a reflective citizen. Accordingly, a scientifically literate person is willing to engage in reasoned discourse about science and technology, which requires the competencies to explain phenomena scientifically, evaluate and design scientific enquiry, and interpret data and evidence scientifically (OECD, 2019).

The Philippines' low performance in science and scientific literacy poses a serious challenge on teachers, as they are the prime movers of education. It can be viewed that teachers possess both the privilege and responsibility in helping to address some issues in our educational system. This privilege is priceless in a sense that teachers 
have a direct influence on the students in shaping their minds and hence, in building the nation's future leaders. However, the price of this privilege is a greater weight of responsibility on the teachers' end.

Teachers bear the greater responsibility in the case of low performance on the National Achievement Test (NAT) in science. In essence, it is no doubt that every nation needs proactive teachers to embody and perform the goals of its education system. As reported by the National Education Testing and Research Centre of the Department of Education (NETRC-DepEd cited in Benito, 2005), on average, high school students' overall performance on NAT is improving from a mean percentage score of 46.80 in School Year (SY) 2004-2005 to 48.90 in SY 2011-2012. With these figures, however, students' performance in science was the lowest (39.49 in SY 20042005 and 40.53 in SY 2011-2012) among the other subjects that are included in NAT; these are Filipino, Mathematics, English, Social Studies, and Critical Thinking Skill Test.

With these results, the accomplishments of few students are overshadowed by the poor performance of many in NAT, which is in fact, the country's measure of quality education. The authors in Science Education Institute and University of the Philippines-National Institute for Science and Mathematics Education (SEI-DOST \& UP NISMED, 2011) found out that, in general, Filipino students have low retention of concepts, have limited reasoning and analytical skills, have poor communication skills, and they cannot apply concepts to real-life problem-solving situation. Likewise, low performance in science of Filipino students can be associated with several factors such as the quality of teachers, the teaching-learning process, the school curriculum, instructional materials and the administrative support (SEI-DOST \& UP NISMED, 2011).

University of the Philippines (UP) Board of Regents, (1997) as revealed by SEIDOST and UP NISMED (2011) discussed the efforts of Science Education Institute of the Department of Science and Technology (SEI-DOST) and University of the Philippines National Institute for Science and Mathematics Education Development (UP NISMED) to address the low performance of Filipino students by focusing on curriculum development, conducting researches, and providing trainings for stakeholders.

However, it is necessary for other stakeholders like the schools under the supervision of the Department of Education to take part and focus on the following concerns: quality of teachers, improvement of the teaching-learning process, 
preparation of the instructional materials and administrative support. It is apparent therefore that National High Schools with Science, Technology and Engineering Program (STEP) should also take part in improving teaching science and research. Students under this program have an additional research subject as an elective of science subjects. Though, most of the students in STEP are not interested in doing research works, they are required to go through the scientific research process and apply it to the Science Investigatory Project (SIP). These SIPs are the direct applications of the scientific method where the students identify problems, proposed a possible solution through conducting experimentations, testing their hypothesis, and presenting their findings.

In the Schools Division of Laguna, Region IV-A, Philippines, students taking the STEP are expected to compete for the annual Science Fair and Congress. The aim of the Science Fair is to promote science and technology consciousness amongst youth. Similarly, identify the most creative and best science researches in the region (DepEd Regional Memorandum No. 270, 2016). The Science Fair features the SIPs from different participating schools competing from the following category: life science, applied science and robotics. It is held during the month of September and participated by teams or individual student from Grades 9 and 10.

In connection with this, research subjects in a National High School have been taught since 2016. For the past years, the said School was not able to compete and produce a SIP output. This only signifies how scientific literacy has been a critical issue in science education. Thus, this study looked into the scientific literacy skill of students under the STEP. The study sought answers to the following questions:

1. What is the scientific literacy of the students in terms of the level of their skills in writing scientific research paper?

2. What is the scientific literacy of the students in terms of the level of their skills in presenting scientific research paper?

3. What are the factors facilitating the student's scientific literacy?

4. What are the factors hindering the student's scientific literacy?

The study aimed to examine the scientific literacy of Junior High School students under the Science, Technology and Engineering (STE) program of a National High School in the Philippines. Specifically, the study: (i) described the scientific literacy of the students in terms of the level of their skills in writing and presenting a scientific 
research paper; and (ii) identified the factors that facilitate and hinder the students' ability to write and present scientific research paper in terms of the teacher (i.e., teacher's personality, teaching style, teaching procedure, teaching strategies, and classroom management), the instructional materials, learning environment, and administrative support.

\section{Materials and methods}

\subsection{Research design}

This study utilized the causal-comparative research design. According to Maheshwari (2018), it is an attempt to identify a causative relationship between an independent variable and a dependent variable. This design suggests to determine the cause or differences among the variables being studied. As cited by Salkind (2010), causalcomparative design seeks to find relationships between variables after an action or event has already occurred. It can also be termed as ex post facto research. One of the characteristics of this design is that the variables that are examined cannot be experimentally manipulated for practical or ethical reasons (Schenker \& Rumrill, Jr., 2004). In this study, the independent variables were the teacher's personality traits, teaching styles, procedure, strategies, classroom management, instructional materials, the learning environment, and administrative support. These $\mathrm{x}$ factors were believed to have contribution to the dependent variable which is the perceived scientific literacy of three groups of Junior High School students such as Grades 7, 8, and 9. The study was conducted upon their completion of the requirements in the research subject.

\subsection{Subjects of the study}

The study employed a stratified random sampling in selecting the subjects. The respondents were composed of randomly selected 76 Junior High School students (i.e. 23 students from Grade 7, 31 from Grade 8, and 22 from Grade 9) under the science curriculum in particular the STEP during the fourth quarter of the School Year 20172018. The sample represented 81 per cent of the total population, which is 94 Junior High School students at a Public National High School in the Philippines. 


\subsection{Instrumentation}

The study utilized the researcher-developed survey questionnaires. The research instrument is composed of two parts that determined the: 1) profile of the students as well as their perceived level of scientific literacy skills in terms of their ability to write and present a scientific research paper; 2) factors affecting their ability to write and present research paper. The students' scientific literacy in terms of writing and presenting a scientific research used five-point performance scale ranging from needs improvement (1) to excellent (5). On the other hand, factors affecting the student's ability to write and present research paper were composed of 2.a) teacher-related factors, 2.b) instructional materials, 2.c) learning environment, and 2.d) administrative support. The indicators for teacher's personality trait, teaching style, teaching procedure, teaching strategies, classroom management and administrative support used the five-point Likert scale ranging from strongly disagree (1) to strongly agree (5). Whereas the instructional materials and the learning environment indicators used another five-point frequency scale ranging from never (1) to always (5) was used.

The questionnaires were also patterned from the elements of teaching and learning, the big five personality traits, Grasha's five teaching styles, including expert, formal authority, personal model, facilitator, and delegator. Grasha (1994) describes the teaching styles as a pattern of needs, beliefs, and behaviours that teachers display in the classroom. The study also utilized the Department of Education Daily Lesson Log, and the evaluation tool for Science Investigatory Projects oral and written presentation. Experts validated the content of the research instrument. The instrument was also pilot tested and reviewed for the internal consistency of questions by conducting the test of reliability with test-retest to a group of 20 Junior High School students from another public high school. The administration of retest was three weeks after the first test. Likewise, the Cronbach-Alpha method was applied, and the result got a total test and retest scores (0.75 and 0.77) with a reliability factor of 'acceptable'.

\subsection{Data collection}

Quantitative and qualitative data were gathered from primary and secondary sources. The primary data were obtained from the ratings of the respondents and the interview from the teachers and the students. Secondary data such as the third quarter Grades 
of the students in Research I, II, and III subjects were also gathered. The result of the oral and written presentation during the conduct of Research culminating activity was also considered in the study.

After the data were gathered, an informal interview from teacher participants and a follow up interview from students were also conducted. Those students who had low ratings in some indicators were included in the interview. A total of 25 students were identified as interview participants.

\subsection{Data analysis}

Descriptive statistics such as mean, frequency distribution, percentage were used to analyse the data obtained from the interviews and questionnaires. The data from students' scientific literacy and the factors affecting their scientific literacy skills development were tallied, tabulated and subjected to mean analysis. To further validate the responses, the Kendall's W or Coefficient of Concordance was used to assess the agreement in the responses among students. The Kendall's W or Coefficient of Concordance for each item ranges from o to 1 . A Kendall's W yield of zero indicates no agreement at all among students, while 1 indicates perfect agreement (Salkind, 2010).

Finally, responses to the interview were transcribed verbatim and were carefully analysed. Themes were formulated from these in order to enrich the discussion of findings on the factors facilitating and hindering the student's scientific literacy.

\section{Results and discussion}

\subsection{Profile of the student respondents}

Of the 76 respondents who participated in the study, 67 per cent were female, while 34 per cent were male. The largest percentage of the female students (29 per cent) appeared from Grade 8. Thirty-three per cent were 13 years old, 28 per cent were 14 . The age group 13 to 14 belongs to Grades 7 and 8. While the age group 15 to 16 were in Grade 9.

In terms of the third grading performance in Research subjects, most respondents (42 per cent) obtained a grade from the range 86- 90 (proficient). Followed by 32 per cent who gained the Grades from 81- 85 (approaching proficiency). Majority of the respondents' academic performance fall on average. 


\subsection{Students' Scientific Literacy Skill in Writing Research Paper}

Table 1 presents the comparison of the respondent's perceived rating on their ability to write research paper per year level. Across the Grade levels, the overall mean was described as good $(\overline{\mathrm{x}}=\mathbf{2 . 8 3})$. Respondents believed that they could write a good research paper (SIP), for it has been discussed in the class. They also underscored that the examples were available at hand. Furthermore, they were able to observe one Division competition exhibit. Among the three, Grade 9 respondents got the highest mean score of 3.35 (good).

Table 1. Perceived rating on research writing across grade levels

\begin{tabular}{|c|c|c|c|c|}
\hline \multirow[t]{2}{*}{ Writing a Research Paper } & \multicolumn{3}{|c|}{ Grade Level } & \multirow{2}{*}{$\begin{array}{l}\text { Overall } \\
\text { Mean }\end{array}$} \\
\hline & 7 & 8 & 9 & \\
\hline \multicolumn{5}{|l|}{ Title } \\
\hline $\begin{array}{l}\text { Formulate brief and comprehensive } \\
\text { title }\end{array}$ & 3.52 & 2.77 & 3.32 & 3.20 \\
\hline $\begin{array}{l}\text { Create a title relevant to the objectives } \\
\text { of the research }\end{array}$ & 3.43 & 2.94 & 3.41 & 3.26 \\
\hline \multicolumn{5}{|l|}{ Abstract } \\
\hline $\begin{array}{l}\text { Write an abstract that contains } \\
\text { objectives, methodology, and results } \\
\text { and conclusion in capsule from } \\
\text { Introduction }\end{array}$ & 2.57 & 2.55 & 3.05 & 2.72 \\
\hline \multicolumn{5}{|l|}{ A. Background of the Study } \\
\hline Identify the origin of the problem & 3.57 & 3.10 & 3.64 & 3.43 \\
\hline $\begin{array}{l}\text { Indicate rational (justification) of the } \\
\text { study }\end{array}$ & 3.09 & 2.58 & 3.45 & 3.04 \\
\hline \multicolumn{5}{|l|}{ B. Statement of the Problem } \\
\hline Discuss the research problem & 3.35 & 3.16 & 3.59 & 3.37 \\
\hline Specify the research questions & 3.09 & 2.84 & 3.68 & 3.20 \\
\hline Clearly state the research goal(s) & 3.04 & 2.94 & 3.55 & 3.17 \\
\hline Evidently apply SMART Objectives & 2.70 & 2.32 & 3.05 & 2.69 \\
\hline \multicolumn{5}{|l|}{ C. Significance of the Study } \\
\hline $\begin{array}{l}\text { Determine who and what will be the } \\
\text { benefit from SIP }\end{array}$ & 2.70 & 2.90 & 3.86 & 3.15 \\
\hline $\begin{array}{l}\text { State the potential of the research for } \\
\text { commercialization }\end{array}$ & 2.78 & 2.52 & 3.32 & 2.87 \\
\hline \multicolumn{5}{|l|}{ D. Scope and Limitations } \\
\hline $\begin{array}{l}\text { Discuss the scope and limitations of the } \\
\text { study }\end{array}$ & 3.00 & 2.48 & 3.36 & 2.95 \\
\hline $\begin{array}{l}\text { Set the time frame for conducting the } \\
\text { study }\end{array}$ & 3.30 & 2.32 & 3.18 & 2.94 \\
\hline $\begin{array}{l}\text { Determine the subject and locale of the } \\
\text { study }\end{array}$ & 3.13 & 2.58 & 3.45 & 3.06 \\
\hline Review of Related Literature & & & & \\
\hline
\end{tabular}




\begin{tabular}{|c|c|c|c|c|}
\hline Write comprehensive RRL & 2.35 & 2.48 & 2.82 & 2.55 \\
\hline Organize the RRL well & 2.30 & 2.35 & 2.77 & 2.48 \\
\hline Use appropriate in text citation in RRL & 2.43 & 2.84 & 2.91 & 2.73 \\
\hline \multicolumn{5}{|l|}{ Materials and Methods } \\
\hline Classify the variables in the research & 3.04 & 3.03 & 3.50 & 3.19 \\
\hline $\begin{array}{l}\text { Explain the sample and sampling } \\
\text { procedure in the research }\end{array}$ & 2.91 & 2.58 & 3.36 & 2.95 \\
\hline $\begin{array}{l}\text { Define the treatment given to the } \\
\text { sample of the study }\end{array}$ & 3.09 & 2.39 & 3.50 & 2.99 \\
\hline $\begin{array}{l}\text { Discuss the research design and the } \\
\text { data gathering procedure }\end{array}$ & 3.04 & 2.42 & 3.41 & 2.96 \\
\hline $\begin{array}{l}\text { State the statistical treatment of the } \\
\text { data under study }\end{array}$ & 2.87 & 2.16 & 3.23 & 2.75 \\
\hline \multicolumn{5}{|l|}{ Results and Discussion } \\
\hline $\begin{array}{l}\text { Present my results in an organize } \\
\text { manner }\end{array}$ & 1.39 & 1.90 & 3.23 & 2.17 \\
\hline $\begin{array}{l}\text { Illustrate the results through graphs } \\
\text { and tables with proper labels }\end{array}$ & 1.35 & 1.97 & 3.36 & 2.23 \\
\hline Discuss the results completely & 1.43 & 2.13 & 3.18 & 2.25 \\
\hline $\begin{array}{l}\text { Ensure that the discussions of the } \\
\text { results are relevant to the data } \\
\text { collected }\end{array}$ & 1.39 & 1.87 & 3.18 & 2.15 \\
\hline \multicolumn{5}{|l|}{$\begin{array}{l}\text { Summary, Conclusion, and } \\
\text { Recommendations }\end{array}$} \\
\hline $\begin{array}{l}\text { Write accurate summary of findings and } \\
\text { conclusion }\end{array}$ & 1.39 & 1.84 & 3.36 & 2.20 \\
\hline $\begin{array}{l}\text { Formulate appropriate } \\
\text { recommendations based on the results } \\
\text { of the study }\end{array}$ & 1.35 & 1.77 & 3.55 & 2.22 \\
\hline \multicolumn{5}{|l|}{ Literature Cited/ Bibliography } \\
\hline $\begin{array}{l}\text { Cite properly the sources using } \\
\text { prescribed citation style (i.e., APA) }\end{array}$ & 1.39 & 2.42 & 3.18 & 2.33 \\
\hline Grand Weighted Mean & & & & 2.80 \\
\hline
\end{tabular}

Range: 4:.45-5.00- Excellent, 3.45-4.44- Very Good, 2.45-3.44- Good, 1.45-2.44- Fair, 1.00-1.44- Needs Improvement

The results also deemed that they were very good in writing parts of the introduction and some parts of materials and methods. When asked about their reasons, respondents answered that it was their third year doing chapters 1 to 3 and they like introduction more than the other parts of research paper. They believed it is the easiest part. Some parts of the methodology also got the highest rating, with the descriptive analysis very good. These are classification of variables $(\bar{x}=3.50)$, sampling $(\overline{\mathrm{x}}=3.36)$ and treatment applied $(\overline{\mathrm{x}}=3.50)$. Grade 9 students were able to experience the whole part of the research paper. 
On the other hand, the perceived rating of Grade 7 respondents $(\bar{x}=2.62)$ was higher than Grade 8, which is 2.53. Grade 7 respondents believed that they were very good in the identification of the problem $(\bar{x}=3.57)$, which was confirmed by their research teacher. Several parts of the review of related literature, methodology, were for the reason of having difficulty in terms of the APA format of in-text citation furthermore identifying the independent and dependent variables of the study. Results and discussions, summary, conclusion, recommendation and literature cited were described needs improvement for these were not covered by the lessons in Grade 7.

Whereas Grade 8 respondents rated good in most parts of the introduction. Similar to the reasons of Grade 7 students, Grade 8, regarded RRL and methodology as fair. In most parts of the results and discussion up to literature cited, respondents gave a rating of fair. In particular, they were relating their response to their understanding in writing a simple science paper.

On the contrary, both Research teachers believed that most of the students rating fall on needs improvement in all parts of the scientific research paper. Students under the STE lack reading habit and time management that is why their research output did not meet the highest standard. The teachers also argued that the SIP was done by group of three or by pair. The core leaders did most of the output while some members of the groups were just riders who memorized the lines for oral presentation. Furthermore, it was emphasized that it was the first time to conduct the classroom competition among Grades 9 students. Grades 7 and 8 just participated during the SIP exhibit.

Since SIP uses experimental research design, teachers underscored that students should be well aware of the classification of variables of the study as well as the treatment that will be applied (CRD or RCBD). Formulation of the hypothesis is one of the important tasks in which most of the students failed. In that case, writing of the SIP report becomes more difficult.

In terms of the in-text citation, students appear in need of more practice on paraphrasing, summarizing and direct quoting. Also, in terms of utilizing the built-in citation in Microsoft word or use a software to ease the formatting (APA) of the references.

Reading habit is an important aspect of society which helps people to develop the right mindset and create new ideas (Palani, 2012) towards skills in writing short story reviews text (Amelia, Ramadhan, \& Gani, 2018). In the study of Widya, and Wahyuni 
(2018), they concluded that grammatical mastery gives a significant contribution to the thesis proposal writing of English department Students at STKIP YDB Lubuk Alung, Indonesia. In the same way vocabulary mastery influence significantly the students writing ability (Abidah, Kurniasih, \& Ni'mah, 2019).

In addition, time management is very important, and it may affect individual's overall performance and achievements (Nasrullah \& Khan, 2015). According to Adebayo (2015), lack of proper time management on the part of the students has some impacts on certain academic activities especially in doing the assignment.

\subsection{Students' Scientific Literacy in Presenting Research Paper}

Table 2 on the other hand, presents the respondents' perception of their performance in presenting a scientific research paper. Contrary to the results in writing SIPs, the overall mean in presenting a research paper across all the Grade levels was 2.24 (fair).

Table 2. Perceived rating on research presentation across Grade levels

\begin{tabular}{|c|c|c|c|c|c|}
\hline \multirow{2}{*}{\multicolumn{2}{|c|}{$\begin{array}{l}\text { Presenting the Research Paper } \\
\text { Statements }\end{array}$}} & \multicolumn{3}{|c|}{ Grade Level } & \multirow{2}{*}{$\begin{array}{l}\text { Overall } \\
\text { Mean }\end{array}$} \\
\hline & & 7 & 8 & 9 & \\
\hline \multicolumn{6}{|l|}{ A. Introduction } \\
\hline $\begin{array}{l}\text { 1. Background of } \\
\text { the Study }\end{array}$ & $\begin{array}{l}\text { Sufficiently and concisely } \\
\text { discuss the circumstances } \\
\text { that led to the problem }\end{array}$ & 1.43 & 2.39 & 3.05 & 2.29 \\
\hline $\begin{array}{l}\text { 2. Statement of } \\
\text { the Problem }\end{array}$ & $\begin{array}{l}\text { Clearly and completely state } \\
\text { the problem }\end{array}$ & 1.52 & 2.68 & 3.36 & 2.52 \\
\hline $\begin{array}{l}\text { 3. Significance of } \\
\text { the Study }\end{array}$ & $\begin{array}{l}\text { Adequately and clearly state } \\
\text { justification for doing the } \\
\text { research }\end{array}$ & 1.43 & 2.52 & 3.50 & 2.48 \\
\hline $\begin{array}{l}\text { 4. Scope and } \\
\text { Limitations }\end{array}$ & $\begin{array}{l}\text { Completely and clearly } \\
\text { discuss the scope and } \\
\text { limitations of the study }\end{array}$ & 1.43 & 2.32 & 3.32 & 2.36 \\
\hline $\begin{array}{l}\text { B. Review of } \\
\text { Related Literature }\end{array}$ & $\begin{array}{l}\text { Include relevant and } \\
\text { adequate literature search }\end{array}$ & 1.43 & 2.32 & 2.68 & 2.15 \\
\hline $\begin{array}{l}\text { C. Materials and } \\
\text { Methods }\end{array}$ & $\begin{array}{l}\text { Sufficiently and concisely } \\
\text { describe the materials and } \\
\text { methods used in the study }\end{array}$ & 1.57 & 2.42 & 3.59 & 2.53 \\
\hline $\begin{array}{l}\text { D. Results and } \\
\text { Discussions }\end{array}$ & $\begin{array}{l}\text { Present and discuss the } \\
\text { results completely }\end{array}$ & 1.39 & 1.90 & 3.14 & 2.14 \\
\hline $\begin{array}{l}\text { E. Summary, } \\
\text { Conclusion and } \\
\text { Recommendation }\end{array}$ & $\begin{array}{l}\text { Present a complete summary, } \\
\text { conclusion, and } \\
\text { recommendation }\end{array}$ & 1.39 & 1.97 & 3.18 & 2.29 \\
\hline $\begin{array}{l}\text { II. Organization } \\
\text { and Clarity }\end{array}$ & Plan my presentation well & 1.57 & 1.94 & 3.36 & 2.29 \\
\hline
\end{tabular}




\begin{tabular}{|c|c|c|c|c|c|}
\hline $\begin{array}{l}\text { III. Mastery of the } \\
\text { Subject }\end{array}$ & $\begin{array}{l}\text { Demonstrate thorough } \\
\text { understanding of the subject } \\
\text { matter }\end{array}$ & 1.48 & 1.84 & 3.18 & 2.29 \\
\hline IV. Delivery & $\begin{array}{l}\text { I am relax and confident } \\
\text { during an oral presentation }\end{array}$ & 1.52 & 1.71 & 2.68 & 1.97 \\
\hline $\begin{array}{l}\text { V. Presentation } \\
\text { Aid }\end{array}$ & $\begin{array}{l}\text { Make use of well- prepared } \\
\text { audio-visual materials }\end{array}$ & 1.48 & 1.84 & 3.00 & 2.11 \\
\hline $\begin{array}{l}\text { VI. Time } \\
\text { Management }\end{array}$ & $\begin{array}{l}\text { Finish the presentation with } \\
\text { the prescribed time and } \\
\text { appropriate pacing }\end{array}$ & 1.43 & 1.81 & 3.14 & 2.13 \\
\hline $\begin{array}{l}\text { VIII. Audience } \\
\text { Impact }\end{array}$ & $\begin{array}{l}\text { Sustain the interest of the } \\
\text { audience most of the time }\end{array}$ & 1.52 & 1.97 & 2.77 & 2.09 \\
\hline VIII. Teamwork & $\begin{array}{l}\text { Work with all members of my } \\
\text { group and share equally in } \\
\text { handling the presentation } \\
\text { and open forum }\end{array}$ & 1.52 & 2.35 & 3.14 & 2.34 \\
\hline IX. Punctuality & Present ahead of schedule & 1.48 & 1.94 & 3.14 & 2.18 \\
\hline $\begin{array}{l}\text { Grand Weighted } \\
\text { Mean }\end{array}$ & & & & & 2.26 \\
\hline
\end{tabular}

Range: 4:.45-5.00- Excellent, 3.45-4.44- Very Good, 2.45-3.44- Good, 1.45-2.44- Fair, 1.00-1.44- Needs Improvement

Several probable reasons stated by the respondents were: 1) they were not confident in speaking English when presenting, 2) they exhibited inappropriate body language when nervous, 3) they were afraid of the panels, and 4) they experienced mental blocked when ask a difficult question.

Grade 7 students seemed to have the lowest mean score of 1.48 (fair). The respondents mentioned that they have not experienced presenting the research paper but related their answers to presenting a group project or an individual report.

Grade 8 students ranked a bit higher $(\overline{\mathrm{x}}=\mathbf{2 . 1 2})$, which also has a descriptive equivalent as fair. It can be seen from Table 2 that parts of the introduction were rated good. This is for the reason that during their presentation, the panels gave positive feedback on the statement of the problem and the significance of the study.

Meanwhile, it can be seen from the results that Grade 9 respondents overall rated mean is described as good $(\bar{x}=3.14)$. Here, the Grade 9 students believed that they have the experience in presenting the completed SIPs. It was confirmed by the respondents that the lesson learned during the presentation were worthwhile in becoming better presenters in their next SIP. Also, their view in describing the materials and methods used in the study was very good $(\bar{x}=3.59)$ for it is deemed to be the easiest during the presentation. 


\subsection{Factors Facilitating and Hindering the Students' Scientific Literacy}

\subsubsection{Teachers' Personality Trait}

There are two teachers handling research classes. Teacher A handles Grade 7, and teacher B handles Grades 8 and 9. Both teachers followed the curriculum guide and budget of work prescribed by the Philippine Department of Education for the STEP. Based on the result, the students' rating on the personality traits of the teacher handling research classes was high $(\overline{\mathrm{x}}=4.19)$. Wherein, the respondents agreed across all the variables under the teacher's personality traits.

The overall mean of the three Grade levels were 4.09, 4.16, 4.18 agree, but the highest rating was found in Grade 9. Among the personality traits depicted in Grade 7 , being sociable $\left(\overline{\mathrm{x}}=4.5^{2}\right)$ strongly agree got the highest weighted mean followed by being responsible, calm, happy, and cooperative. The teacher who handled Grade 7 , has been described by the respondents as a jolly and a very approachable person. Moreover, the teacher who handled Grades 8 and 9 was described as hardworking $(\bar{x}=4.58, \quad \bar{x}=4.64)$, responsible, $(\bar{x}=4.58, \quad \bar{x}=4.59)$, self-disciplined $(\bar{x}=4.59)$, imaginative $(\overline{\mathrm{x}}=4.59)$ and intellectual $(\overline{\mathrm{x}}=4.55)$.

The respondents described their teacher as strict and serious. It was also underscored that their research teachers portray self-discipline and responsibility by sticking to the set rules and duties in the class and reprimand students with misbehaviour by counselling not by punishing. Students believed their teachers in research exert much effort in terms of preparing instructional materials since there is no module for this subject matter. However, in terms of emotional stability (unworried), the results for both teachers from Grades 7, 8, and 9 were found the lowest with the mean of $3.43,3.13,3.32$, respectively. Respondents were uncertain if their teachers are unworried. They observed that most of the time, both teachers worry if the respondents will be able to meet the required output in every Grade level.

Moreover, the results of this study support the findings of Kim, Dar-Nimrod, and Mac Cann (2017), which explained that teacher personality characteristics such as conscientiousness (being hard-working and detail-minded), agreeableness (being sympathetic and kind), and emotional stability (having fewer negative emotions such as anxiety) are important factors in achieving students academic success. Teachers' personality traits were associated with students' confidence in achieving an academic goal. However, in the study of Mkpanang (2015) on the personality traits of teachers 
and the students' performance in Physics, it was found that there was a low significant relationship between teachers' personality profile and students' academic achievement in the subject.

\subsubsection{Teaching Styles}

Based on the students' rating regarding their teacher's teaching styles from Grasha's description as an expert, the respondents regarded their teachers being equipped with knowledge and competency they needed for the Science Investigatory Projects. As a formal authority, teacher sets rules, goals and expectations to guide the students on the track they should follow.

Correspondingly, respondents described both teachers give positive and negative feedbacks. For instance, giving merits and demerits in the class. As a personal model, guiding and directing by showing how to do things was given the mean scores of 4.52, 4.65, and 4.64 (strongly agree) across all the Grade levels. It is portrayed by demonstrating laboratory experiments inside the classroom using improvised and indigenous resources. Moreover, providing sample researches and SIPs was also emphasized by the respondents. As a facilitator, guiding by asking questions, exploring options and suggesting alternatives was noted with the highest mean (strongly agree) scores of 4.52, 4.77, and 4.73 from all Grade levels.

However, having consultation hours got the least mean score of 3.78 and 3.77 from Grades 7 and 8 (agree). Both teachers handling Research subjects were given other auxiliary task as the Grade level coordinator and the Grade level guidance counsellor of the school. Comparing the results across all the Grade levels on teaching styles as a delegator, it was found out that Grade 9 has the highest $(\bar{x}=4.32, \bar{x}=4.41)$.

Respondents described their teacher being available as a resource person and allows them to work in autonomy. Grade 9 respondents indicated that they were tasked to complete the Science Investigatory Project paper and oral presentation that is the reason they were given much time to work in autonomy and via consultation with the Research teacher. Grade 7 teacher was given the lowest mean scores of 3.87 and 3.83 for the same criteria. One possible reason for that result is students were working with close supervision by the teacher. For Grade 7 is more on foundational concepts and theories that will help the students in higher year level.

The study of Frunză (2014) affirmed that effective teaching styles also depend on the students' learning styles. More so, willingness to experiment with teaching strategies will help in developing an effective teaching style for the students. However, 
the findings of the study deviated from the study of Stanford (2014), which revealed that the mathematical scores of students in classroom who were taught using facilitator and delegator teaching styles were significantly higher than the scores of students from an expert, formal authority, and personal model teaching styles.

\subsubsection{Teaching Strategies}

The teaching strategies help the teacher to engage the students in the teaching and learning process. In general, the perceived rating of the respondents towards teaching strategies used by their research teachers was 4.24 (agree). Moreover, criterion from cooperative learning and technology integration got the highest mean score $(\overline{\mathrm{x}}=4.65)$.

Under cooperative learning, working by partners or peer tutoring was the highest across the Grade levels interpreted as strongly agree $(\overline{\mathrm{x}}=4.61, \overline{\mathrm{x}}=4.65$, and $\overline{\mathrm{x}}=4.68)$. Working with their chosen partner or the pairs selected by the teachers were allowed as long as they will accomplish the set objectives and outcomes for a certain topic. This indicates that students across all the Grade levels are willing to work with pairs and teams for they can express themselves better and progressed better results.

The findings on cooperative learning supports the study of Altun (2017), which emphasized the favourable effect of cooperative learning on students' performance. The development of students' social and personal skills can also be achieved in cooperation-based learning since it provides support and cooperation from the group (Altun, 2017).

In terms of technology integration, reporting the results of class activity through PowerPoint presentation was also high 4.77 (strongly agree) for both Grades 8 and 9. It is an indication that the facilities like laptop, projector, screen, and speaker are already available for the teaching and learning process, whether provided by the teachers or the school. Lessons were also delivered through PowerPoint presentation as emphasized by both teachers. The findings on technology integration verified by Weathersbee (2008), where the impact of technology and academic performance was analysed. The results specified that technology integration in the classroom increased the students' performance in science, mathematics and reading in selected public schools in Texas.

Meanwhile, criterion from the inquiry-based instruction was found highest $(\bar{x}=4.74)$ - strongly agree at Grade 8 while the use of differentiated instruction got the lowest (3.36)- agree in Grade 9. The results signify that the incorporation of respondents' multiple intelligences is not highly evident in the teaching and learning 
process. One probable reason for that is the number of students in the class and the number of hours in teaching a particular lesson.

The findings on the use of inquiry-based instructions further support the earlier studies done by Alameddine, and Ahwal, (2016); Abdi (2014); and Bayram, Oskay, Erdem, Özgür, and Şen (2013). The studies revealed that inquiry-based instructions increase students' performance. On the other hand, the findings on the use of differentiated instruction were supported by the identified challenges on the learning curve and planning time (Stetson, Stetson \& Anderson, 2018).

\subsubsection{Teaching Procedure}

The teaching procedure is the day to day lesson delivery of the teachers based on the Daily Lesson Log (DLL) prescribed by the Department of Education. The prescribed DLL also follows the Gagne's nine events of instructions such as: 1) gaining attention, 2) informing learners of objectives, 3) stimulating recall of prior learning, 4) presenting the content, 5) providing guidance, 6) eliciting performance, 7) providing feedback, 8) assessing performance and 9) enhancing retention (Gagne, 1997). It was found that the overall mean for all the Grade levels was high $(\overline{\mathrm{x}}=4.41)$.

The findings indicate that both teachers followed the prescribed DLL. It is interesting to note that both Grades 7 and 8, got mean scores of 4.50 and 4.55, which most of the respondents strongly agreed. Found in Grade 9 was the highest weighted mean of 4.77 (strongly agree) which indicates that the teacher always presents examples of new lesson. Respondents shared that their teacher brought a magazine, a printed journal, sample experiments, and a lot of video presentations if the resources are not available at hand.

The results of the study support Miner, Mallow, Thekee, and Barnes (2015), which revealed that Gagne instructional events enhanced teachers 'mastery, enthusiasm and effectiveness. Thus, the grades of the students increased. Moreover, the findings also support the study of Ngussa (2014), which showed that the higher the performance of the students the greater the perception on Gagne instructional events.

\subsubsection{Classroom Management}

Classroom management is a way in which the teacher ensures that the class maximizes learning time without disruption. It can be in a form of seating arrangement, assigning of task, creating a harmonious environment, or even delivering the lesson. 
It was found out that across the Grade levels under the study, the overall mean is 4.16 with the descriptive analysis agree. With the same criteria across the Grade level, it was found out that the highest score with the description strongly agree can be seen only in Grade $9(\overline{\mathrm{x}}=4.50)$. Respondents confirmed that their teacher showed respect and believed that they are becoming mature that is why there is no need to scold them often. The result also shows that positive discipline reinforces positive behaviour among learners.

The use of instructional time effectively got the second highest mean score of 4.45 (strongly agree). However, respondents uttered that their teachers always begin with the end in mind making the class agitated and overwhelmed with ideas. The next highest score $(\overline{\mathrm{x}}=4.36)$ with the descriptive analysis agree, talks about seating arrangement that encourages an interactive teaching and learning process. It was mentioned by the respondents that seating arrangement changes from regular lecture type to circle time, U shape seat plan, by group, by pairs, and sometimes with no chairs. Seating arrangement depends on the activity prepared by the teacher.

The findings on classroom management support the study of George, Sakirudeen, and Sunday (2017), which revealed that the academic performance of students who experienced classroom management (verbal instruction, corporal punishment, instructional supervision, delegation of authority to learners) differs from those who do not. Additionally, the major findings of Ahmad and Hussain (2017) indicated that there is a positive relationship between teachers' classroom management strategies and the performance or achievement of the students.

\subsubsection{Instructional Materials}

Instructional materials are tools that help the teachers in facilitating the day-to-day lessons. The use of instructional materials can maximize the learning potential of the students as well as the time allotted in teaching. Findings show that the perceived mean rating on the instructional materials used by the teacher in facilitating the lesson was 3.44 described as about half of the time. This indicates that the Junior High School students perceived that their teachers used varieties of instructional materials as much as they could.

In general, using PowerPoint presentations, sample researches, and supplementary reading materials appeared to be the most commonly used instructional materials by the Research teachers. On the other hand, the students agreed that their teachers used learning modules once in a while, with mean ratings 
of 2.39, 1.45, and 2.14, respectively. They related their answers with the science learners' modules but not the research module since it was not yet developed.

Studies on the use of instructional materials revealed that that students taught with instructional materials performed better than those taught without instructional materials. The use of instructional materials generally improved students' understanding of concepts and led to high academic achievements (Olayinka, 2016; Adalikwu \& Iorkpilgh, 2013).

\subsubsection{Learning Environment}

The status and availability of school facilities have direct and indirect impacts on the learning of students. Results revealed that the students were able to utilize all available school facilities for research-related activities about half of the time, with overall mean of 2.99. Classrooms appeared to be the most commonly used school facility for the conduct of the research studies of Grades 7 to 9. When asked about their reason, they explained that there is not enough time to go and avail other learning facilities. They have 10 subjects per day with different requirements.

On the other hand, across all levels, DOST Star Books facility was the least tapped resource that is available in the school, with perceived ratings of 1.57, 2.26, and 2.27 from Grades 7, 8, and 9, respectively. The respondents felt that they were not trained to operate the DOST Star Books, which are housed inside the library. They also mentioned that they were hesitant to do research works in the library since there are no clear policies or guidelines in using the resources in the library. Students also identified that the science laboratory was always closed.

Additionally, computer laboratory lacks internet access most of the time. Also, only one computer with internet access can be utilized by a class. The respondents reiterated that classes were also held at the computer laboratory that is why students opted to maximize the use of their mobile phones instead of going to the computer laboratory. In the same manner, teacher respondents agreed to the statements given by the students. They also emphasized the unavailability of teacher in charge in the laboratory and the lack of training guide to utilize the DOST star books.

The findings on the learning environment, specifically school facilities affirmed the findings of study Al-Enezi (2002) which revealed that there is a positive significant relationship exists between student achievement scores and building conditions. On the contrary, student achievement, attendance and completion rate measures were not found to be statistically significant in relation to school facility conditions as 
measured by the Total Learning Environment Assessment (TLEA) at the 0.05 level; second, discipline, or behaviour, was found to be significantly related to the TLEA (Mcgowen, 2007).

\subsubsection{Administrative Support}

Grade 7 students seemed to be uncertain on the support given by the school administrators during the time that they took their research subject. Specifically, the overall mean from Grade 7 students was 3.14, which described as about half of the time.

On the other hand, Grades 8 and 9 students both agreed that appropriate administrative support was given to them during the time they took their Research subjects. In particular, they both agreed that the school administration primarily encouraged research exposure visits, with means of 4.35 and 4.91, respectively.

Within each Grade level, providing moral and financial support received the least ratings. These are 3.00, 3.29 and 4.09 from Grades 7, 8, and 9, respectively. Nevertheless, the overall mean of 3.85 suggests that the research students of Grades 7 to 9 agreed that they received support from the administrators of the school.

On the contrary, the teacher respondents pointed out that financial support was not given all the time. The department raised funds to send the students for most of the competition. Funds were raised from the contributions of teachers or private individual. From the point of view of the teachers, administrative support encourages the students to achieve academic success.

Nevertheless, the findings do not support the study of Bello, Ibi, and Bukar (2016) which revealed that that 1) there were no significant relationships between principal's initiative administrative styles and students' academic performance; 2) no significant relationships between consideration structure of principals' administrative styles and students' academic performance; 3) no significant relationships between participatory administrative styles of principals' and student academic performance in senior secondary schools; and 3) among the three leadership styles, none is the best predictor of students' academic performance in Taraba State secondary schools.

Furthermore, Coefficient of Concordance revealed congruence in the perceptions of the students regarding the factors that facilitate and hinder their scientific literacy skills development. Basically, the statistical findings showed a strong to perfect agreement in the students' perceptions of all the factors examined (Kendall's W ( $\mathrm{df}=8$, 
$\mathrm{n}=76)=0.60, \mathrm{p}=0.00$ ). Table 3 presents the summary of each of these factors. The findings were all statistically significant.

Table 3. Summary of facilitating factors of students' scientific literacy skills development

\begin{tabular}{llll}
\hline Factors & Mean & SD & Kendall's W \\
\hline Teaching Personality & 4.23 & 0.38 & 1.00 \\
B. Teaching Style & 4.33 & 0.38 & 1.00 \\
C. Teaching Strategy & 4.26 & 0.37 & 1.00 \\
D. Teaching Procedure & 4.42 & 0.45 & 1.00 \\
E. Classroom Management & 4.16 & 0.44 & 1.00 \\
F. Instructional Materials & 3.41 & 0.67 & 1.00 \\
G. School Facilities & 3.01 & 0.85 & 0.93 \\
Administrative Support & 3.85 & 0.88 & 1.00 \\
\hline
\end{tabular}

Kendall's W level of agreement: 0.00 No; 0.10-Weak; 0.30-Moderate; 0.60-Strong; 1.00-Perfect

\section{Conclusions and implications}

It can be concluded that although the results of the scientific literacy skills in terms of writing scientific research paper was good already, yet, there are several parts of the research paper that must be taken into consideration. In addition, the respondents believed that they were having difficulties in presenting the research paper. Thus, they need a lot of trainings and exposure to become better presenters.

The findings of the study also suggested that the perceived scientific literacy of students were influenced by factors primarily the teacher's personality traits, teaching styles, procedure, strategies, classroom management, instructional materials, the learning environment, and administrative support. Thus, to improve the scientific literacy skills of the students as to presenting scientific research in written and oral form, such factors should be given importance just as how scientific literacy is important in the society.

The following are the recommended strategies to improve the scientific literacy among Junior High School students:

For the Research Teachers' personality and teaching style, since the findings showed the least scores on teachers' emotional stability (unworried), it is suggested to find ways of improving teacher's communication, empathy and comfort to increase the effectiveness in teaching research as a subject. An increase in teacher's availability during consultation hours is an important avenue for giving feedback and encouragement to the students having difficulty in their identified research problems. Also, helping the students to work in autonomy will empower them to aim higher in 
the field of scientific research. Differentiated instruction should also be considered while utilising local and indigenous instructional materials. This will help the students to relate well to the learning activities and thus maximize their learning experiences.

For the Science Coordinator and Teachers, the formulation of some policy guidelines in the use of the library, DOST STAR BOOKS, computer laboratory, science laboratory and other learning resources will be a great help for the students as to setting directions. Developing a research learning module will help to standardise the lesson across different Grade levels. Additionally, drafting a proposal for the STEP of activities or the annual plan will also encourage teachers to perform better.

For the School Leaders, the increase of support to the Science Department in terms of moral and financial, will be a significant factor in boosting students' morale as well. Henceforth, allowing the science/research teachers to attend seminars or trainings that will improve their teaching skills and become more abreast with current research practices. Students' exposure to the field of research should also be prioritised by the educators and educational leaders. Allowing them to visit schools that already excel in the field of Science Investigatory Projects is a good way to adopt techniques and best practices. Furthermore, strengthening linkages through partnership with the Local Government Units (LGUs) and non-government organizations will help in identifying other sources of fund. This will aid the trainings and acquisition of laboratory equipment that can be utilized by the students in the development of their scientific literacy skills.

Now that the world is continuously overwhelmed by vast amount of information, the development of scientific literacy skills is becoming more important than ever. This ultimately amplifies the significant role of educational leaders and educators in promoting scientific literacy in science education. For a populace with well-developed scientific literacy can better cope with many of its problems. Hence, people will be able to make better judgements and informed decisions that will affect the quality of life beyond personal and social. And this in turn leads to the betterment of the entire nation. 


\section{References}

Abidah, K. H., Kurniasih, K., \& Ni'mah, D. (2019). The Influence of Grammar and Vocabulary Mastery toward Writing Ability In the Second Semester Students of English Department. Jurnal Penelitian, Pendidikan, dan Pembelajaran, 14(12). http://www.riset.unisma.ac.id/index.php/jp3/article/view/3915

Abdi, A. (2014). The Effect of Inquiry-Based Learning Method on Students' Academic Achievement in Science Course. Universal journal of educational Research, 2(1), 37-41. https://doi.org/10.13189/ujer.2014.020104

Adalikwu, S. A., \& Iorkpilgh, I. T. (2013). The influence of instructional materials on academic performance of senior secondary school students in chemistry in Cross River State. Global Journal of Educational Research, 12(1), 39-46.

Adebayo, F. A. (2015). Time Management and Students Academic Performance in Higher Institutions, Nigeria A Case Study of Ekiti State. International Research in Education, 3(2), 1-12. http://dx.doi.org/10.5296/ire.v3i2.7126

Ahmad, S., \& Hussain, Ch. (2017). Relationship of Classroom Management Strategies with Academic Performance of Students at College Level. Bulletin of Education and Research, 39(2), 239-249.

Alameddine, M. M., \& Ahwal, H. W. (2016). Inquiry based teaching in literature classrooms. Procedia-Social and Behavioral Sciences, 232, 332-337.

Al-Enezi, M. M. (2002). A study of the relationship between school building conditions and academic achievement of twelfth grade students in Kuwaiti public high schools (Doctoral dissertation, Virginia Tech).

Altun, S. (2017). The effect of cooperative learning on students' achievement and views on the science and technology course. International Electronic Journal of Elementary Education, 7(3), 451-468.

Amelia, S., Ramadhan, S., \& Gani, E. (2018). The effects of cooperative learning model type TPS and reading habits toward skills in writing short story reviews text. In International Conference on Language, Literature, and Education (ICLLE 2018) (pp. 512-518). Atlantis Press. https://dx.doi.org/10.2991/iclle-18.2018.86

Bayram, Z., Oskay, Ö. Ö., Erdem, E., Özgür, S. D., \& Şen, Ş. (2013). Effect of inquiry based learning method on students' motivation. Procedia-Social and Behavioral Sciences, 106, 988-996. https://doi.org/10.1016/J.SBSPRO.2013.12.112

Bello, S., Ibi, M. B., \& Bukar, I. B. (2016). Principals' Administrative Styles and Students' Academic Performance in Taraba State Secondary Schools, Nigeria. Journal of Education and Practice, 7(18), 62-69.

Benito, N. V. (2005). National Achievement Test Results Fourth Year SY 2005-2006. National Education Testing and Research Center, Department of Education. Retrieved o5 June 2020 from http://www.fnf.org.ph/downloadables/National Achievement Test-4th Year (05-06).pdf

Department of Education (DepEd) (2019). PISA 2018 National Report of the Philippines. Retrieved o5 June 2020 from https://www.deped.gov.ph/wpcontent/uploads/2019/12/PISA-2018-Philippine-National-Report.pdf

Deped Regional Memorandum No. 270, S. of 2016. (2016). DepEd Regional Memorandum No. 270, Series of 2016.

Dragoş, V., \& Mih, V. (2015). Scientific literacy in school. Procedia-Social and Behavioral Sciences, 209, 167-172.

Frunză, V. (2014). Implications of teaching styles on learning efficiency. Procedia-Social and Behavioral Sciences, 127, 342-346. 
Gagne, R. M. (1997). Mastery Learning and Instructional Design Originally published in 1988, PIQ 1.1. Performance Improvement Quarterly, 1O(1), 8-19.

George, I. N., Sakirudeen, A. O., \& Sunday, A. H. (2017). Effective classroom management and students' academic performance in secondary schools in Uyo local government area of Akwa Ibom state. Research in Pedagogy, 7(1), 43.

Grasha, A. F. (1994). A matter of style: The teacher as expert, formal authority, personal model, facilitator, and delegator. College teaching, 42(4), 142-149.

Kim, L. E., Dar-Nimrod, I., \& MacCann, C. (2018). Teacher personality and teacher effectiveness in secondary school: Personality predicts teacher support and student self-efficacy but not academic achievement. Journal of Educational Psychology, 110(3), 309. https://doi.org/10.1037/eduo000217

Leonen, J. N. (2017). Pinay student wins P20M in global science competition | Inquirer Global Nation. Retrieved 28 May 2018 from http://globalnation.inquirer.net/162938/pinaystudent-wins-p20-m-global-science-competition-bjc-leyte-student-science-competitionhillary-andales

Maheshwari, V. K. (2018). Causal-comparative research. Retrieved May 24, 2018, from http://www.vkmaheshwari.com/WP/?p=2491

McGowen, R. S. (2007). The impact of school facilities on student achievement, attendance, behavior, completion rate and teacher turnover rate in selected Texas high schools. Texas A\&M University.

Miner, M. A., Mallow, J., Theeke, L., \& Barnes, E. (2015). Using Gagne's 9 events of instruction to enhance student performance and course evaluations in undergraduate nursing course. Nurse educator, $40(3), 152$.

Mkpanang, J. T. (2015). Personality Profile of Teachers and their Students' Performance in PostBasic Modern Physics. African Research Review, 9(1), 159-168.

Mohapatra, A. K. (2013). Exploring Perspective of Scientific Literacy: an Overview. Cogn. Discourses Int. Multidiciplinary J, 1(1), 79-88.

Nasrullah, S., \& Khan, M. S. (2015). The Impact of Time Management on the Students' Academic Achievements. Journal of Literature, Languages and Linguistics 11 (2015), 66-71. https://core.ac.uk/reader/234693030

Ngussa, B. M. (2014). Gagne's Nine Events of Instruction in Teaching-Learning Transaction: Evaluation of Teachers by High School Students in Musoma-Tanzania. International Journal of Education and Research, 2(7), 189-206.

Olayinka, A.R.B. (2016). Effects of Instructional Materials on Secondary Schools Students' Academic Achievement in Social Studies in Ekiti State, Nigeria. World Journal of Education, 6(1), 32. https://doi.org/10.5430/wje.v6n1p32

Organization for Economic Co-operation and Development (OECD) (2018). PISA Results in focus 2015, PISA, OECD Publishing, Paris. Retrieved 24 June 2020 from https://www.oecd.org/pisa/pisa-2015-results-in-focus.pdf

Organization for Economic Co-operation and Development (OECD) (2019). PISA 2018 Assessment and Analytical Framework, PISA, OECD Publishing, Paris. Retrieved 24 June 2020 from https://doi.org/10.1787/b25efab8-en

Palani, K.K. (2012). Promoting reading habits and creating literate society. Journal of Art, Sains and Commerce, (online). III 2, (1), 90-94, ISSN: 2231-4172. https://korg.pw/o9-08-10.pdf

Rodriguez-Espinosa, J. M. (2005). The importance of scientific literacy in our Society. In Astrophysics, and How to Attract Young People into Physics (pp. 28-31).

Salkind, N. J. (2010). Encyclopedia of research design: Volume 1. SAGE Publications. https://doi.org/10.4135/9781412961288 
Schenker, J. D., \& Rumrill Jr, P. D. (2004). Causal-comparative research designs. Journal of vocational rehabilitation, 21(3), 117-121.

Science Education Institute and University of the Philippines-National Institute for Science and Mathematics Education (SEI-DOST \& UP NISMED) (2011). Science Framework for Philippine Basic Education. Manila: SEI-DOST \& UP NISMED. Retrieved from http://www.sei.dost.gov.ph

Stanford, A. (2014). The effects of teachers' teaching styles and experience on elementary students' mathematical achievement.

Stetson, R., Stetson, E., \& Anderson, K. A. (2017). Differentiated instruction, from teachers' experiences. Retrieved 20 June 2017 from http://www.aasa.org/SchoolAdministratorArticle.aspx?id=6528

Turiman, P., Omar, J., Daud, A. M., \& Osman, K. (2012). Fostering the 21st century skills through scientific literacy and science process skills. Procedia-Social and Behavioral Sciences, 59, 110-116.

Weathersbee, J. C. (2008). Impact of technology integration in public schools on academic performance of Texas School Children (Doctoral dissertation, Texas State University-San Marcos).

Widya, S. O., \& Wahyuni, I. (2018). The Correlation Between Grammar Mastery and Writing Thesis Proposal at STKIP YDB Lubuk Alung. Jurnal Arbitrer, 5(2), 75-80. http://arbitrer.fib.unand.ac.id/index.php/arbitrer/article/view/114 